\title{
Crisis-related Changes in the Specialisation of Advanced Economies in Global Value Chains
}

Magdolna Sass and Andrea Szalavetz

Analysis of globalisation induced gains and losses necessitates not only new types of data to substitute for the ones compiled in traditional trade statistics but also new analytical approaches. This paper surveys the literature that addresses the evolution of the global value chain approach, an analytical perspective that is able to capture the causes and consequences of the ongoing process of global reorganisation of production more in depth than earlier theories. Our specific focus is on one hand, advanced economy actors' changing activity specialisation in the new global division of labour and the related changes in their competitiveness, and on the other hand crisis-related changes in global value chains. We conjecture that advanced economy actors have been continuously shifting their specialisation towards 'the edges of the value chains' into activities requiring higher skills, and resulting in a higher value capture for them. We show that this process has further accelerated during the crisis.

KEYWORDS global value chains, advanced economies, activity specialisation, trade in tasks, value capture, crisis 


\section{Introduction}

Globalisation has brought about fundamental changes in the international division of labour thatare poorly traced using the available statistical data and methodological approaches (Sass, Fifekova, 2011). Case studies on the value distribution in products where global value chains (GVCs) link together stakeholders responsible for individual stages of value adding (e.g. Ali-Yrkkö et al., 2011; Dedrick et al., 2010) have managed to shed new light on longstanding competitiveness puzzles and policy debates, concerned with the consequences of the long continuing decline in advanced economies' share in world manufacturing production, coupled with their accumulating trade deficits in in high-technology manufacturing industries in particular. The recent phenomenon of the offshoring and offshore outsourcing of advanced, high value-adding activities to less developed countries (Contractor et al., 2010; Manning et al., 2008) has added fuel to ongoing policy debates.

The concerns of developed economies' regarding the adverse economic consequences of the apparently non-abating increase in the range and depth of offshored activities, which accelerated after the 2008-2011 crisis, can be contrasted with the puzzling fact that advanced economy manufacturing firms' value added to production ratio keeps increasing (UNIDO International Yearbooks of Industrial Statistics). It is argued in this article that the answer to this puzzle lies in advanced economy manufacturing firms' activity specialisation in the new global division of labour, which is strongly related to their robust and sometimes increasing value capture. This article focuses on changes in the GVC activities of advanced economies: how lead firms' and advanced economies' activity specialisation evolves in GVCs in tandem with offshoring and offshore outsourcing - a hitherto underinvestigated issue.

The dynamics of the evolution of advanced economies' activity specialisation was significantly influenced by the 2008-2011 crisis that provoked a sharp fall in foreign trade volumes: in fact, the extent of trade decrease was greater than the decline in output. Thus international trade can be regarded as one of the great 'victims' of the world crisis (Escaith et al., 2010). At the same time, it was one of the main channels through which the crisis was transmitted between countries. Our analysis brings together the two related perspectives: globalisation- and crisis-related changes in global value chains. Beginning with a summary of the analytical background, we present briefly the emergence and evolution of the GVC framework of analysis, and the trade-in-task perspective (section 2). This is followed by a survey of patterns of advanced-economy actors' changing specialisation within GVCs (section 3). Section 4 focuses on crisis-induced transformations in GVCs and the implications thereof for advanced economies. Section 5 concludes. 


\section{The GVC framework of analysis}

In a holistic view of value creation, the concept of GVC refers to all (tangible and intangible) activities - carried out by geographically dispersed, networked economic actors - that contribute to the creation, sale and support the end use of a product or service. The GVC framework of analysis moves beyond merely scrutinising the distribution of production activities (and related flows of trade in intermediates) and investigates all the activities of firms' value chains, including production-related support activities and activities that enhance the intangible value of products. Hence, the GVC framework incorporates and contributes to a better understanding of trade, not only in manufactures, but also in business services, a constituent of global trade whose volume is expanding at a significant rate (Gereffi and Fernandez-Stark, 2010).

In contrast to trade-based analyses, the point of departure for scholars investigating the transformation of the global economy from an organisational perspective using firms and inter-firm networks as the central unit of analysis (Gereffi, 2005) is that the simple increases in the volume of integrative trade and in the geographical spread of economic activities cannot be regarded as the key feature of the recent global transformation. The key novelty is rather the functional integration of globally dispersed activities (Dicken, 2003).

According to Baldwin (2006), globalisation and the slicing up of value chains proceeded in two waves. The first unbundling - 'the end of the necessity of making goods close to the point of consumption' (:7) - started with the technological advances of the first industrial revolution, which have led to the first dramatic fall in transportation costs and consequently to an explosion in trade. The recent wave of globalisation that started a couple of decades ago (in the 1980s) triggered the second unbundling: 'the end of the need to perform most manufacturing stages near each other' (:7), coupled with functional unbundling, facilitated by the information technology revolution.

Scholars trying to extrapolate from recent trends (the point of departure being that technological advances have made production tasks increasingly separable, tradable, standardisable and offshorable, which has resulted in an ever finer division of labour) have predicted that global shifts in production will continue, and that, with a steady increase in the number of 'footloose tasks', with activities increasingly dispersed and to low-cost economies (Friedman, 2005). In fact, with digitisation, codification and modular product architecture, more tasks are becoming commoditised than ever before (Davenport, 2005; Manning et al., 2012). The relocation of production is often followed by the relocation of certain $R \& D$ tasks 
as well, in order to reduce the physical distance between $R \& D$ engineers and the operation, and to 'ensure that problems are solved at source as they arise' (Lanz et al., 2011, p. 4).

As for the adverse effect of offshoring on developed economies, several scholars argue, that a careful distinction has to be made between contestable activities, which are bound to result in dispersion, and non-contestable activities, the geographical concentration of which is not reduced (Leamer, 2007). Given that these latter activities account for the dominant share of value added, this suggests that the competitiveness of advanced economies is not threatened by the increasing number of footloose activities.

This debate and the recent puzzling manifestations of advanced economies' competitiveness prompted our main research question: we investigate the changing patterns of advanced economies' specialisation in the current 'world of outsourcing and offshoring', in which 'the boundaries of ... firms have ... simultaneously shrunk organizationally and expanded geographically' (Contractor et al., 2010, p. 1418).

Next we briefly discuss the emergence and evolution of the trade-in-tasks perspective - a recent methodological approach which allows precise insight into the patterns and dynamics of countries' specialisation.

\section{Trade-in-tasks perspectives}

A far-reaching finding of early GVC scholars was that what matters for competitiveness is not what countries produce (the technology mix of production and export) and how their world trade share evolves, but rather the dynamics of exporters' value capture, in other words how their share in the total value added of their export products evolves (Gereffi and Fernandez-Stark, 2011; Kaplinsky and Morris, 2001). Economic performance is determined by firms' added value, which in turn shapes their value capture. GVC scholars started to measure companies' move from low to high(er) value-adding activities by identifying generic business functions and gathering data on them (Sturgeon, 2008; Brown, 2008; Sturgeon and Gereffi, 2009; Eurostat').

In contrast to the implicit assumption of these scholars that both firms and countries increasingly become specialised in specific functions within GVCs, case study evidence suggests that several subsidiaries (as well as suppliers) host 'identical' business functions: support functions (administration, HR, finances, accounting, transportation, logistics, distribution, procurement, general management, customer support). In addition, and those functions that pertain to the intangible constituents of the value chain, for example design, research and development, engineering, ICT services, knowledge-intensive software development are decentralised (Contractor et al. 2010; Pavlínek and Zenka, 2011; 
Szalavetz, 2012; Winter, 2010). Although peripheral subsidiaries are seemingly entrusted with identical functions as headquarters, the activities related to the individual functions are far from being identical. There are large inter-subsidiary differences in the complexity and value-adding capability of individual business functions, given that business functions themselves can be sliced up. Business functions are decomposable and consist of dozens of sub-functions (Contractor et al., 2010).

Lead firms can decide which sub-function is located and to which subsidiary. Empirical evidence suggests that, even in the case of advanced high value-adding activities, the slices (the tasks) that are offshored are less knowledge-intensive than the segments of the same business function that are kept in-house: these latter are the tasks that require nonroutine, cognitive and analytical competencies. Furthermore, with the organisational decomposability of business functions, no single function can be unambiguously described by simple dichotomies such as low-tech and labour-intensive and low value-adding; or advanced and knowledge-intensive and high value-adding.

Decomposable as they are, broad business functions, as units of international trade analyses, give an incomplete and potentially misleading picture in cross-country comparisons. This deficiency called for an even finer level of trade analysis that takes account of the fact that the many kinds of activities related to specific business functions can be disaggregated, and that the ones that can be standardised, codified and routinized are increasingly offshored.

Hence, it is the spatial distribution of corporate activities - or even the location of each value-adding act (Stehrer et al., 2011) - that should be examined, rather than the distribution of business functions. Grossman and Rossi-Hansberg (2008) model trade as an exchange of identifiable and discrete units of work. This recognition motivated data compilation and analyses of trade at the task level (Lanz et al., 2011), an initiative that later developed into a joint OECD-WTO designed measurement framework and database of trade in value added (cf. WTO: Made in the World http://www.wto.org/english/res e/statis e/miwi e/miwi e.htm; see also: Maurer and Degain, 2012).

These new analytical approaches can compensate for the above-detailed deficiencies of business function-based analyses. Moreover, they contribute to a better understanding of the features that make specific activities offshorable: standardisation, codification, routinisation, skilled labour intensity, that is the degree to which it requires cognitive and analytical competencies (Autor et al., 2003) - note that these characteristics determine the added value of individual activities.

The changing activity specialisation within GVCs of advanced economies 
Analyses of countries' specialisation are usually concerned with industry mixes by technology intensity, and with the drivers and competitiveness implications of changes in specialisation (Midelfart-Knavrik et al., 2002). Industry-level analyses associate the competitiveness of industries with the productive factors used most intensively in the given industry (Baldwin, 2011). This line of thinking has, however, left several questions unanswered, producing at the same time some hard-to-explain puzzles, such as the historical strength of the advanced economies of European low- and medium-tech (LMT) industries, and the remarkable stability of LMT sectors in terms of both employment and value added. ii

A much debated issue was the relation between specialisation and macroeconomic performance, which above and beyond theory, has important policy implications. Despite extensive analytical and empirical efforts it remains ambiguous as to whether Europe's lagging growth and productivity performance (Dalum et al., 1999; Fagerberg et al., 2000; Sapir, 2004) can be ascribed to its traditional specialisation patterns.

While some authors argued that traditional industry-level taxonomies (i.e. the classification of innovativeness along the 'low-tech - high-tech' spectrum) are misleading: non-science-based industries are also innovative, albeit on measures other than sciencebased ones (Mendonça 2009; von Tunzelmann and Acha, 2005). The point of departure of another stream of research is more related to our investigations. Kirner et al., 2009; and Peneder, 2010 showed that no industry is internally homogeneous, rather each industry is composed of a wide variety of high-, medium- and low-tech firms. Low-technology industries are therefore not to be equated with low-technology firms, and conversely, high-tech industries also include a considerable number of non-innovative firms. Hence, 'industry' cannot be considered the appropriate level for competitiveness analyses. A related research strand argues that, as a consequence of widespread vertical specialisation (Hummels et al., 2001), specialisation in high-tech exports does not necessarily reflect indigenous technological capabilities (Srholec, 2007). This is what explains large intra-GVC, crosscountry differences in value creation and value capture (Dedrick et al., 2010; Ali-Yrkkö et al., 2011).

These findings suggest that it is the industry-level distribution of activities (rather than the distribution of industries themselves) that determines competitiveness and sheds light on the real nature of specialisation. Baldwin $(2006,2011)$ asserts that in the current wave of globalisation, competition is manifest not at the level of sectors and industries (as in traditional trade theories), but rather at the level of individuals (and the tasks they perform). This recognition produced the most recent move in an ongoing process, in which the unit of analysis of international specialisation shifted to increasingly finer levels: from industries (and 
industry-associated skill groups) to goods, from goods to intermediates (Stehrer et al., 2011), and most recently to business functions and to tasks (activities).

Within the international business literature there is anecdotal evidence of various aspects of advanced-economy firms' changing activity specialisation. One example is the transformation of manufacturing firms into service providers. In order to add value, increase profitability and withstand competition from low-cost producers, manufacturing companies try to integrate service provision into their manufacturing products (the 'servitisation of products' in Vandermerwe and Rada, 1988; Martinez et al., 2010) or to achieve convergence of manufacturing and services (Stehrer et al., 2012). They compete with business solutions (Prencipe et al., 2003), a combination of products, services networks and infrastructures, delivered as a system to the customer (Davies, 2004). Manufacturing firms are considered predominantly service providers once their revenues from service activities exceed revenues from products. A related concept is that of factory-less firms or hollow corporations: they specialise in activities such as design, brand management, marketing, logistics and retail, but outsource manufacturing (Dicken, 2011).

The theoretical context underpinning these phenomena is Porter's (1986) assertion about the two dimensions of firms' international competition: (i) coordination, and (ii) configuration of global activities. According to Hobday et al. (2005), systems integration is one of a lead firm's core capabilities. However, the authors provide a narrow definition of systems integration, as bringing together 'all the necessary inputs for a system ... hightechnology components, subsystems, software, skills, knowledge, engineers, managers, and technicians to produce a product...' (Hobday et al., 2005:1110). By contrast, the trade-intasks perspective of systems integration incorporates many other tasks in addition to the items listed above, for example support services, services incorporated into the products, and service types of corporate activities that enhance the intangible value of products. Since each of these latter activities can be sourced internationally, systems integration through the global configuration of activities and their coordination really can be regarded as lead firms' core competence. Systems integration concerns configuring activities in an optimal way, in order to benefit from both of 'the simultaneous "twin" processes of vertical integration and disintegration' (:1111), from 'both specialisation and integration' (:1136).

Recent research on firms' critical capabilities (surveyed by Schmid and Schurig, 2003) has also identified organisational and marketing-type capabilities as critical. These latter capabilities, above all that of systems integration - including the capability to (i) identify the core competences and determine the balance of vertical integration and specialisation, (ii) find the right suppliers (and geographical location), and manage and control the global sourcing process, (iii) integrate, coordinate and control distributed knowledge bases (Brusoni et al., 2001), and (iv) design and implement the global marketing and sales strategy - 
complement firms' technological and developmental capabilities, and are deemed critical for business success in general, and for value capture in particular.

Considering Baldwin's (2012) taxonomy of 'headquarter economy', versus 'factory economy' advanced economies' specialisation concerns, and is increasingly restricted to the above type of core capabilities: to system integration and coordination. These activities are associated with the highest value added as demonstrated both by Mudambi's (2008) and Baldwin's (2012) theoretical model, the so-called smile curve economics and by the results of exercises that decompose the value-added shares of the individual constituents of intangible capital (Piekkola, 2011). According to Piekkola, it is organisational capital, i.e. activities that contribute to the generation of organisational capitaliii that can be associated with the highest value capture. The smile curve that depicts the distribution of value added at each stage of the chain (figure 1) illustrates this point. It makes obvious that production activities generate much less value added, than pre- and post-manufacturing services-type activities.

\section{Insert Figure 1 about here}

The specialisation of advanced economy firms in organisational capital-related activities and business functions is examined indirectly by a research strand concerned with the (re)location of multinational companies' (divisional) headquarters (HQ). HQs are important sources of high-value-adding jobs, and they represent hubs of high-end business services concentrated around them. In addition, the most important managerial functions (decisionmaking about the configuration of activities, coordination and corporate governance, global financial and strategic management, etc.) are concentrated in firms' HQs, and consequently most organisational capital is associated with the $\mathrm{HQ}$. It is therefore important to monitor changes in their spatial distribution. Despite the importance and the performance implications of the topic, data on this aspect are scarce and research has been confined mainly to identifying the motivations for, and the performance implications of $\mathrm{HQ}$ relocation (Birkinshaw et al., 2006; Laamanen et al., 2012; Strauss-Kahn and Vives, 2009).

\section{Crisis and GVCs: Catalyst or stabiliser of trade flows}

Advanced economies gradually evolving GVC-specialisation experienced a sudden exogenous shock with the economic and financial crisis that broke in 2008. In this section we first examine why the fall of international trade was greater than that of GDP. Our second question is whether (and how) foreign trade acted as a transmitter of the crisis. Finally we seek to answer, whether the crisis brought about changes in the level, extent and other characteristics of the participation of advanced economies in GVCs. 
GVC-related factors were included as possible transmission mechanisms when investigating the causes of the trade decline (and especially its differing depth in various countries) and the role of international trade in 'transporting' the crisis from one country to another (see, among others, Baldwin, 2009; Freund, 2009; Milberg and Winkler, 2010). These authors hypothesised that it is the organisation of international production in GVCs that caused a greater drop in trade than in GDP. Baldwin $(2009,2011)$ actually suggested that GVCs played a key role in the nature of the 'great trade collapse'. This meant that GVCs, a relatively neglected area of research up till then, have come to the forefront in terms of analysing changes in world trade during the crisis. The GVC approach proved to be fruitful in getting better insight into the anatomy of the crisis, in spite of that fact that as we will see, the results of empirical studies perceived as related to the GVC approach differ from each other.

First it must be noted, that there are some empirical papers that do not find the GVC factor significant. For example, Rose and Spiegel (2010) could not find strong evidence that international trade linkages acted as transmitters of the crisis. According to their results, countries with higher exposure to the US economy (in terms of the share of their exports to the US) performed better during the crisis. Thus, trade linkages did not play a negative role in helping the crisis travel through countries. As for the main factors playing a role in the trade decline, other authors ( for example Chor and Manova, 2010) - found that adverse credit conditions played an important role in transmitting the impact of the crisis to trade flows. The dependence on external finance by French exporters is also underlined as the most important factor by Bricongne et al. (2011).

Nevertheless, several empirical studies showed that factors connected to GVCs may have played a role in the significant decrease in foreign trade volumes during the crisis. Other analyses underline the importance of GVCs in 'spreading' the crisis to ever more countries: however, results differ in terms of the length, sign (positive or negative) and importance of that effect. Moreover, there are studies, which found that GVCs played a stabilising role concerning trade flows during the crisis. As for the relative importance of GVCs among the factors contributing to the trade decline, an analysis conducted by the OECD (Cheung and Guichard, 2009) showed that demand factors and tight credit conditions were the main causes of the fall in world trade during the crisis years. The unexplained part of the trade decline, which represented about 10-20 per cent of the total fall, may reflect a breakdown in GVCs. Similarly, Escaith et al. (2010) use historical data and also show that GVCs played a role in explaining the larger decrease in trade than in GDP. They present two GVC-related factors in that respect. The first is the composition effect: 'the initial demand shocks linked to the credit crunch concentrated disproportionally on consumer durables and 
investment goods, the most vertically integrated industrial sectors' (Escaith et al., 2010, p. 110). The second factor is called the 'bullwhip effect', which refers to inventory adjustments, the size of which becomes ever greater the further along the value chain one goes.

Shortage of trade finance has already been shown to have played a role in the decline of foreign trade. Milberg and Winkler (2010) applied a more nuanced approach to the problem of trade finance and linked this to GVCs. They showed that trade finance shortages have a greater effect on international trade if it is organised in GVCs, because the close relationships between the participating companies result in a quick transmission of the problem along the value chain.

Sectoral differences however, may be important. For example Stehrer et al. (2011a) analyse trade in intermediates and (separately) trade in parts and components, in order to show whether the breaking up of GVCs played any role in the trade decline during the crisis years. They use CN (Combined Nomenclature) categories at a disaggregated level. First, they show how the elasticity of trade with respect to income increased in the OECD countries, comparing the two periods of 1961-84 and 1985-2009. They explain that this is at least partly driven by the increased vertical specialisation of countries, i.e. the presence of GVCs, as countries export and import a large amount of parts and components and other intermediate products ('intermediates' being parts and components plus semi-finished goods plus primary goods). The increased income elasticity of trade is then explained by the fact that trade flows are registered as gross (i.e. the full amounts), whereas GDP relies on the concept of value added (a kind of net value). During the crisis, in real terms they found a slight decline in the share of parts and components in total trade for the EU-27. They showed industry differences: on the one hand, the share of parts and components as a measure of the degree of vertical specialisation varied considerably, with electrical machinery, machinery and equipment, transport equipment and the automotive sector having the highest shares; on the other hand, industrial differences were also present in the extent of the decline in export and import volumes during the crisis. In this latter respect, the automotive sector stands out; other sectors that are less 'GVC intensive' on the basis of the trade shares of parts and components also experienced a large fall. According to the authors, the trade fall may be an outcome of demand and supply-side factors, disruptions in GVCs being one of the many causes.

On the other hand, certain studies underline the stabilising impact of GVCs in terms of sustaining of trade levels or at least moderating the fall in trade flows. Thus, seemingly unrelated to our topic, Alfaro and Chen (2010) analyse the reaction and role of FDI during the global financial crisis. They examine firm-level data from more than 100 countries for 2007 and 2009. Their results can be related to the GVC approach, because they distinguish and examine three channels through which FDI impacts upon the performance of companies: 
production linkages, financial linkages and multinational networks. From our point of view, the most important results are that multinationals engaged in activities with vertical production linkages weathered the crisis better than their local counterparts. On the other hand, horizontal type of FDI was affected more negatively. Moreover, companies operating as part of a multinational network on average performed better; here again, horizontal production linkages were affected more negatively than vertically integrated ones. Thus GVCs may have played a stabilising role. Van Bergeijk (2013) analysed trade data for 42 countries, and found that international value chains had a major diminishing impact concerning the fall in world trade during 2008-9.

Behrens et al. (2011) found, in the case of Belgium, that involvement in global value chains has some explanatory power for the fall in both exports and imports during the crisis, though domestic operations were equally affected. According to their results, the trade fall was mainly caused by demand-side factors. They also point out that the fall in foreign trade is explained overwhelmingly by the intensive margin of trade (exporters reduced the volume of exports), while the extensive margin (i.e. reduction in the number of exporters) was negligible. This is in line with the findings of Békés et al. (2012), who analysed firm survey data from seven countries (Austria, France, Germany, Hungary, Italy, Spain and the United Kingdom). They also found that 'networking' and links with other companies (outsourcing or controlling other companies) helped firms to fare better during the crisis. This result can also be interpreted within the GVC framework. On the other hand, companies controlled by other firms were in a worse position. Thus the place of the firm in the production chain is an important determinant of the effect of the crisis. Case study evidence in the apparel sector presented by Gereffi and Frederick (2010:186) also showed that involvement in GVCs could have played a mitigating effect during the crisis - as when for example lead firms supported suppliers who were suffering from trade finance problems.

Bems et al. (2011) use a global input-output framework containing data from 55 countries. They found that GVCs (proxied by trade in intermediates) significantly mitigated the fall in world trade, as the extent of the decline in trade in intermediaries was less than half the fall in trade in final goods. They also used the concept of vertical specialisation - thus a subset of trade in intermediates - for their further investigations. Like Stehrer et al. (2011a), they distinguished between gross trade and value-added trade, and found that value-added trade decreased less than gross trade, which meant that vertical specialisation contributed (albeit modestly) to the greater decrease in total trade.

The two seemingly opposing results (that GVCs played an important role in the trade fall and that GVCs acted as stabilizers for trade flows) are reconciled to some extent by a dynamic analysis of Altomonte et al. (2012), who use transaction-level French trade data, matched with ownership data for 2007-09, to determine whether GVCs contributed to the 
significant fall in international trade flows during the crisis. They found that trade in intermediaries was the most important cause of the decrease in foreign trade flows; thus the role of GVCs was substantial in the trade decrease during the crisis. However, they also found that this type of trade rebounded faster - i.e. 'trade originated within hierarchies of firms reacted faster to the negative demand shock, but has also recovered faster in the following months than arm's length trade' (Altomonte et al., 2012, p. 23). They also show the presence of the 'bullwhip effect' of inventory adjustment.

As for the research question whether the crisis brought about changes in the level, extent and other characteristics of the participation of advanced economies in GVCs, the crisis-related shifts in GVCs are connected to the changes in their drivers. According to World Economic Forum (2012), these drivers are increased energy and transport costs, which reduce the length of GVCs; the emergence of new players, who secure access to resources, causing a surge in competition; the possibly changing role of China with the shifts in its growth models; further decrease in information technology costs and the changing global map of economic growth. It is important to note however, that as Cameron (2011) points out, while theories are abundant, there is 'little systematic empirical work on the drivers of the growth of global value chains' (p. 92) However, the report of the World Economic Forum (2012) found it likely that the global geography of GVCs would change towards a larger role of developing countries. Accetturo et al. (2011) also shows that for an increasing number of firms in advanced countries, outsourcing or offshoring will be an obliged decision in the post-crisis era.

The connection between the crisis and GVCs is analysed from a development and developing-country perspective by the papers collected in the book by Cattaneo et al. (2010b). While this volume concentrates on developing countries, the analysis provides important indirect insights into the changing position of advanced countries in the analysed field. One of the main conclusions of the book is that GVCs proved to be resilient to the crisis; they became (and remain) important actors in the world economy and important modes of organisation for the production process in certain activities. Moreover, they call attention to the (possibly) longer-term impacts of the crisis on world trade - above all, its diversification in terms of a shift from the advanced countries to the South, not only in supply but also in demand. A second long-term effect is the trend towards consolidation at the country and company levels. This means, at the country level, a shift towards large developing countries, especially China; at the company level it signifies an ever more pronounced preference on the part of lead firms for larger, more competitive and productive first-tier suppliers, which are able to operate globally. The report of the World Economic Forum (2012) also concentrates on the implications for developing countries. Their conclusions for advanced countries' economic policy are that because of the very likely shift 
in the geography of GVCs, developed countries will be more and more concerned about retaining jobs parallel with the advancement and increased role of developing countries in GVCs.

In summing up the empirical literature written up to now on the role of GVCs in the crisis, the results are at best ambiguous. This can be attributed partly to the different approaches and different methodologies, datasets and time horizons used. However, it seems obvious that, on the one hand, GVCs played a role in transmitting the crisis and had an amplifying effect in the first few months of it in terms of the decrease in international trade. On the other hand, they also had a certain stabilising effect, at least in the slightly longer run. This may have been caused by the reversal of the bullwhip effect, as well as by the fact that companies inside the value chain helped each other (e.g. by providing trade finance) or tried to start to rebuild the network, which operated before the crisis.

As for the changing role of GVCs as a result of the crisis, it is clear that GVCs are here to stay; but consolidation tendencies in them are ubiquitous. As Godart et al. (2009, p. 7) underline: "sunk costs matter", thus the rebuilding of the pre-crisis production networks and GVCs may take considerable time and may involve different players at certain levels of the GVCs, which may affect the relative level and extent of participation of advanced countries in them. On the basis of the surveyed studies it is all the more probable that in the era of increasing competitive pressures, companies in advanced economies are less and less able to retain less skilled activities, which are increasingly relocated to developing and emerging economies. On the other hand, actors in advanced economies are increasingly specialised in activities at the two sides of value chains, resulting in a higher value capture for them.

\section{Conclusions}

This paper reviewed the current literature on advanced economies' activity specialisation after "globalisation's second unbundling" and on the impact of the crisis on GVCs. We addressed two related perspectives: globalisation- and crisis-related changes in global value chains - in order to make predictions with respect to the ways these countries' activity specialisation is bound to evolve.

One lesson that can be learned from the literature reviewed in this paper is that the unbundling of business functions prompted advanced economy actors' activity specialisation within GVCs to shift to the sides: both to the left and - even more - to the right side of the smile curve. Crisis and the ensuing geographic and organisational consolidation of GVCs have accelerated this ongoing tendency. The consequence for advanced countries is a 
stronger specialisation on the activities requiring higher skills at the two ends of the GVC, while the reliance on less advanced countries with lower wages in the "middle" of the GVCs has grown more robust. Changes in the international division of labour will without doubt have welfare consequences, which is a topic for future research. Moreover, country-level specialisation on GVC and non-GVC sectors determines the manoeuvring room of national economic policies, which is also to be addressed.

It is important to emphasize again that while the theoretical framework for analysing GVCs is strong; our concrete knowledge about them and their role in the national economies is relatively limited. This is mainly due to the inability of available data to capture and characterise the phenomenon and the difficult, lengthy and meticulous task of compiling more adequate sets of data, in spite of all the efforts that have been made in that field of research - as it is shown in the article. That is why on one hand, as an international exercise, the initiative of the OECD-WTO to measure trade in value-added ${ }^{\text {iv }}$ is an important step towards helping to improve our understanding of the GVCs. On the other hand, obviously, more sector, country and company case studies would be needed. GVC research is without doubt yet an unfinished business.

\section{References:}

Accetturo, A., Giunta, A. and Rossi, S. (2011), 'Italian Firms between Crisis and New Globalization', Bank of Italy Occasional papers no 86, January 2011.

Alfaro, L., and Chen, M., (2010), 'Surviving the Global Financial Crisis: Foreign Direct Investment and Establishment Performance', Harvard Business School Working Papers, 10110, Harvard Business School.

Ali-Yrkkö, J., Rouvinen, P., Seppälä, T., and Ylä-Anttila, P., (2011), 'Who Captures Value in Global Supply Chains? Case Nokia N95 Smartphone', Journal of Industry, Competition and Trade, Vol. 11, No. 3.

Altomonte, C., Di Mauro, F., Ottaviano, G., Rungi, A., and Vicard, V., (2012), 'Global Value Chains During the Great Trade Collapse. A Bullwhip Effect?', European Central Bank, Working Paper Series, No. 1412.

Autor, D.H., Levy, F., and Murmane, R.J., (2003), 'The skill content of recent technological change: An empirical exploration', Quarterly Journal of Economics, Vol. 118, No. 4.

Baldwin, R., (2012), Global Supply Chains: Why They Emerged, Why They Matter, and Where They Are Going. Fung Global Institute Working Paper, 2012-1.

Baldwin, R., (2011), Integration of the North American Economy and New-paradigm Globalization, In: Sydor, A., (ed.), (2011), Global Value Chains: Impacts and Implications. Foreign Affairs and International Trade Canada, www.international.gc.ca. pp. 43-76.

Baldwin R., (2009), 'Introduction: The Great Trade Collapse: What caused it and what does it mean?', in The great trade collapse: Causes, consequences and prospects, VoxEU.org ebook, available at:

http://www.voxeu.org/index.php?q=node/4297. 
Baldwin, R., (ed.), (2006), 'Globalisation: the great unbundling(s)', background paper to the project: Globalisation challenges for Europe, Secretariat of the Economic Council, Finnish Prime Minister's Office, available at:

http://appli8.hec.fr/map/files/globali-sationthegreatunbundling\%28s\%29.pdf

Behrens, K., Corcos, G., and Mion, G., (2011), 'Trade Crisis? What Trade Crisis?', Centre Interuniversitaire sur le Risque, les Politiques Économiques et l'Emploi (CIRPÉE), Working Paper, 11-17.

Békés, G., Halpern, L., Koren, M., and Muraközy, B., (2012), 'Still standing: how European firms weathered the crisis - The third EFIGE policy report', Bruegel Blueprint Series, Vol. 15.

Bems, R., Johnson, R.C., and Yi K.M., (2011), 'Vertical Linkages and the Collapse of Global Trade', American Economic Review, Vol. 101, No. 3.

Birkinshaw, J., Braunerhjelm, P., Holm, U., and Terjesen, S., (2006), 'Why Do Some Multinational Corporations Relocate Their Headquarters Overseas?', Strategic Management Journal, Vol. 27, No. 7.

Bricongne, J. C., Fontagné L., Gaulier G., Taglioni D. and Vicard V. (2011), 'Firms and the global crisis: French exports in the turmoil,' Working papers 265, Banque de France. Available at http://www.banque-france.fr/uploads/tx_bdfdocumentstravail/DT265.pdf

Brown, S., (2008), 'Business Processes and Business Functions: a new way of looking at employment', Monthly Labor Review, Vol. 131, No. 12.

Brusoni, S., Prencipe, A., and Pavitt, K., (2001), 'Knowledge Specialization, Organizational Coupling, and the Boundaries of the Firm: Why Do Firms Know More Than They Make?', Administrative Science Quarterly, Vol. 46, No. 4.

Cameron, R., (2011), Canada"s State of Trade. Trade and Investment Update 2011. Available at http://www.international.gc.ca/economisteconomiste/assets/pdfs/SoT_2011_e.pdf

Cattaneo, O., Gereffi, G., and Staritz, C., (eds.), (2010), Global Value Chains in a Postcrisis World. A Development Perspective, Washington, The World Bank.

Cheung, C., Guichard, S., (2009), 'Understanding the World Trade Collapse', OECD Economics Department Working Papers, No. 729, Paris, OECD Publishing, http://dx.doi.org/10.1787/220821574732.

Chor, D., and Manova, K., (2010), 'Off the Cliff and Back? Credit Conditions and International Trade During The Global Financial Crisis', NBER Working Paper, No. 16174.

Contractor, F., Kumar, V., Kundu, S.K., and Pedersen, T., (2010), 'Reconceptualizing the Firm in a World of Outsourcing and Offshoring: The Organizational and Geographical Relocation of High-Value Company Functions', Journal of Management Studies, Vol. 47, No. 8.

Dalum, B., Laursen, K., and Verspagen, B., (1999), 'Does Specialization Matter for Growth?', Industrial and Corporate Change, Vol. 8, No. 2.

Davenport, T.H. (2005), 'The Coming Commoditization of Processes', Harvard Business Review, Vol. 83, No. 6.

Davies, A. (2004), 'Moving base into high-value integrated solutions: A value stream approach', Industrial and Corporate Change, Vol. 13, No. 5.

Dedrick, J., Kraemer, K.L., and Linden, G., (2010), 'Who profits from innovation in global value chains?: a study of the iPod and notebook PCs', Industrial and Corporate Change, Vol. 19, No. 1.

Dicken, P., (2011), Global Shift. Mapping the Changing Contours of the World Economy, 6th edition, Thousand Oaks, CA and London: SAGE Publication. 
Dicken, P., (2003), Global Shift. Reshaping the global economic map in the 21st century, 4th edition, Thousand Oaks, CA and London: SAGE Publication.

Escaith, H., Lindenberg, N., and Miroudot, S., (2010), Global Value Chains and the Crisis: Reshaping International Trade Elasticity, in Cattaneo et. al. (2010), pp. 73-125.

Fagerberg, J., (2000), 'Technological progress, structural change and productivity growth: a comparative study', Structural Change and Economic Dynamics, Vol. 11, No. 4.

Freund, C., (2009), 'The trade response to global downturns: historical evidence', Policy Research Working Paper, No. 5015. Washington, DC, World Bank.

Gereffi, G., (2005), 'The Global Economy: Organization, Governance, and Development', in Smelser, N.J., and Swedberg, R., (eds.), The Handbook of Economic Sociology, 2nd edition, Princeton, NJ, Princeton University Press, pp. 160-182.

Gereffi G, Fernandez-Stark K. 2011. Global value chain analysis: A primer. Durham, NC: Center on Globalization, Governance and Competitiveness, Duke University. http://www.cggc.duke.edu/pdfs/2011-05-31 GVC analysis a primer.pdf

Gereffi, G., and Fernandez-Stark, K., (2010), The Offshore Services Value Chain: Developing Countries and the Crisis, in Cattaneo et al., (2010), pp. 335-372.

Godart, O., Görg, H. and Görlich, D., (2009), Back to normal? The future of global production networks after the crisis. Kiel Policy Brief, Kiel Institute for the World Economy, available at: http://www.ifw-members.ifw-kiel.de/publications/back-to-normal-the-future-of-globalproduction-networks-after-the-crisis

Grossman, G., and Rossi-Hansberg, E., (2008), 'Trading tasks. A simple theory of offshoring', American Economic Review, Vol. 98, No. 5.

Hobday, M., Davies, A., and Prencipe, A., (2005), 'Systems integration: a core capability of the modern corporation', Industrial and Corporate Change, Vol. 14, No. 6.

Hummels, D., Ishii, J., and Yi, K.M., (2001), 'The Nature and Growth of Vertical Specialization in World Trade', Journal of International Economics, Vol. 54 No. 1.

Kaplinsky, R., and Morris, M., (2001), A handbook for value chain research, http://www.inti.gov.ar/cadenasdevalor/manualparainvestigacion.pdf

Kirner, E., Kinkel, S., and Jaeger, A., (2009), 'Innovation paths and the innovation performance of low-technology firms - An empirical analysis of German industry', Research Policy, Vol. 38, No. 3.

Laamanen, T., Simula, T., and Torstila, S., (2012), 'Cross-border relocations of headquarters in Europe', Journal of International Business Studies, Vol. 43, No. 1.

Lanz, R., Miroudot, S., and Nordås, H.K., (2011), 'Trade in Tasks', OECD Trade Policy Working Papers, No. 117, OECD Publishing http://dx.doi.org/10.1787/5kg6v2hkvmmw-en.

Leamer, E.E., (2007), 'A Flat World, A Level Playing Field, a Small World After All, or None of the Above? A Review of Thomas L. Friedman's The World is Flat', Journal of Economic Literature, Vol. 45, No. 1.

Manning, S., Massini, S., Peeters, C., and Lewin, A.Y. (2012), Global Co-Evolution of Firm Boundaries: Process Commoditization, Capabilities Development, and Path Dependencies. CEB Working Paper, No. 12/009, Université Libre de Bruxelles, Solvay Brussels School of Economics and Management Centre Emile Bernheim

Manning, S., Massini, S., and Lewin, A.Y., (2008), 'A Dynamic Perspective on NextGeneration Offshoring: The Global Sourcing of Science and Engineering Talent', Academy of Management Perspectives, Vol. 22, No. 2. 
Martinez, V., Bastl, M., Kingston, J., and Evans, S., (2010), 'Challenges in transforming manufacturing organisations into product-service providers', Journal of Manufacturing Technology Management, Vol. 21, No. 4.

Maurer, A. and Degain, C. (2012). 'Globalization and Trade Flows: What you see is not what you get!' Journal of International Commerce, Economics and Policy, Vol. 3, No. 3.

Mendonça, S., (2009), 'Brave old world: Accounting for 'high-tech' knowledge in 'low-tech' industries', Research Policy, Vol. 38, No. 3.

Midelfart-Knarvik, K.H., Overman, H.G., Redding, S.J. and Venables, A.J. (2002), 'Integration and industrial specialisation in the European Union', Revue Economique Vol. 53, No. 3.

Milberg, W., and Winkler, D., (2010), Trade, Crisis, and Recovery: Restructuring Global Value Chains, in Cattaneo et al., (2010), pp. 23-72.

Pavlínek, P., and Zenka, J., (2011), 'Upgrading in the automotive industry: firm-level evidence from Central Europe', Journal of Economic Geography, Vol. 11, No. 3.

Peneder, M., (2010), 'Technological regimes and the variety of innovation behaviour: creating integrated taxonomies of firms and sectors', Research Policy, Vol. 39, No. 3.

Piekkola, H., (2011), 'Intangible Capital: The Key to Growth in Europe', Intereconomics, Vol. No. 4.

Prencipe, A., Davies, A., and Hobday, M., (eds.), (2003), The Business of System Integration, New York, Oxford University Press.

Porter, M.E., (1986), Competition in global industries, Boston, Harvard Business School Press.

Rose A.K., and Spiegel, M., (2010), 'Cross-Country Causes and Consequences of the 2008 Crisis: International Linkages And American Exposure', Pacific Economic Review, Vol. 15, No. 3.

Sapir, A., (ed.), (2004), An Agenda for Growing Europe. The Sapir Report, Oxford, Oxford University Press.

Sass, M., and Fifekova, M., (2011) Offshoring and outsourcing business services to Central and Eastern Europe: some empirical and conceptual considerations. European Planning Studies, Vol. 19, No. 9.

Schmid, S., and Schurig, A., (2003), 'The development of critical capabilities in foreign subsidiaries: disentangling the role of the subsidiary's business network', International Business Review, Vol. 12, No. 6.

Srholec, M., (2007), 'High-Tech Exports from Developing Countries: A Symptom of Technology Spurts or Statistical Illusion?', Review of World Economics, Vol. 143, No. 2.

Stehrer, R., Ali-Yrkkö, J., Hanzl-Weiss, D., Foster, N., Rouvinen, P., Seppälä, T., Stöllinger, R., and Ylä-Anttila, P., (2011a), 'Trade in Intermediate Products and EU Manufacturing Supply Chains', wiiw Research Reports, No. 369, Vienna, The Vienna Institute for International Economic Studies.

Stehrer, R. et al., (2012), 'Convergence of Knowledge-Intensive Sectors and the EU's External Competitiveness', wiiw Research Reports, No. 377, Vienna, The Vienna Institute for International Economic Studies.

Strauss-Kahn, V., and Vives, X., (2009), 'Why and where do headquarters move?', Regional Science and Urban Economics, Vol. 39, No. 2.

Sturgeon, T.J., (2008), 'Mapping integrative trade: conceptualising and measuring global value chains', International Journal of Technological Learning, Innovation and Development, Vol. 1, No. 3. 
Sturgeon, T.J., and Gereffi, G., (2009), 'Measuring success in the global economy: international trade, industrial upgrading, and business function outsourcing in global value chains', Transnational Corporations, Vol. 18, No. 2.

Szalavetz, A., (2012), 'Micro-level aspects of knowledge-based development: Measuring quality-based upgrading in MNCs' Hungarian subsidiaries', International Journal of Knowledge-Based Development, Vol. 3, No. 4.

van Bergeijk, P. A. G.,(2013), 'The World Trade Collapse and International Value Chains: A Cross-Country Perspective', International Economic Journal, Vol. 27, No. 1, March 2013, 41 53

Vandermerwe, S., and Rada, J., (1988), 'Servitization of business: Adding value by adding services', European Management Journal, Vol. 6, No. 4.

von Tunzelmann, N., and Acha, V., (2005), 'Innovation in 'low-tech' industries', in Fagerberg, J., Mowery, D., and Nelson, R., (eds.), The Oxford Handbook of Innovation, Oxford, Oxford University Press, pp. 407-432.

Winter, J., (2010), 'Upgrading of TNC subsidiaries: the case of the Polish automotive industry', International Journal of Automotive Technology and Management, Vol. 10, No. 2-3.

World Economic Forum (2012) 'The Shifting Geography of Global Value Cahins: Implications for Developing Countries and Trade Policy', Available at http://www3.weforum.org/docs/WEF_GAC_GlobalTradeSystem_Report_2012.pdf

\section{Acknowledgements}

This paper is an updated version of the one, prepared originally as a background study for the European Competitiveness Report - 2012. The funding of the European Commission and of the Hungarian National Research Fund (OTKA K83982) is gratefully acknowledged. The authors are indebted to János Gács and Robert Stehrer for their comments on an earlier version of the article. The opinion expressed in this paper is that of the authors, and does not represent the European Commission's official position.

\section{Notes on contributors}

Magdolna Sass is senior research fellow at the Institute of Economics CERS, HAS. Her main research fields are inward and outward foreign direct investments and foreign trade and related policies in the East-Central European countries, with special attention to developments in Hungary. Her most recent publications include "Crisis and upgrading: The case of the Hungarian automotive and electronics sectors", Europe-Asia Studies, 65(3) with Andrea Szalavetz; "Internationalisation of innovative SMEs in the Hungarian medical precision instruments industry", Post-Communist Economies 24:(3); "Emerging multinationals and the role of virtual indirect investors: the case of Hungary" Eastern European Economics 50:(2) with Katalin Antalóczy and Andrea Éltetö and "Outward foreign direct investments and emerging multinational companies from Central and Eastern Europe: the case of Visegrad countries" Eastern European Economics 50:(2) with Mariusz-Jan Radlo.

Correspondence to: Magdolna Sass, IE CERHAS, 1112 Budapest, Budaörsi út 45., Hungary. Email: sass.magdolna@krtk.mta.hu

Andrea Szalavetz is senior research fellow at the Institute for World Economics CERS, HAS. Her main research fields include the economics of innovation, and global value chain issues. Her recent paper, together with Magdolna Sass is "Crisis and upgrading: The case of the Hungarian automotive and electronics sectors", Europe-Asia Studies, 65(3). She is author of "Micro-level aspects of knowledge-based development: Measuring quality-based 
upgrading in MNCs Hungarian subsidiaries", International Journal of Knowledge-Based Development, 3(4). 
Figure 1

\section{Smile-curve economics}

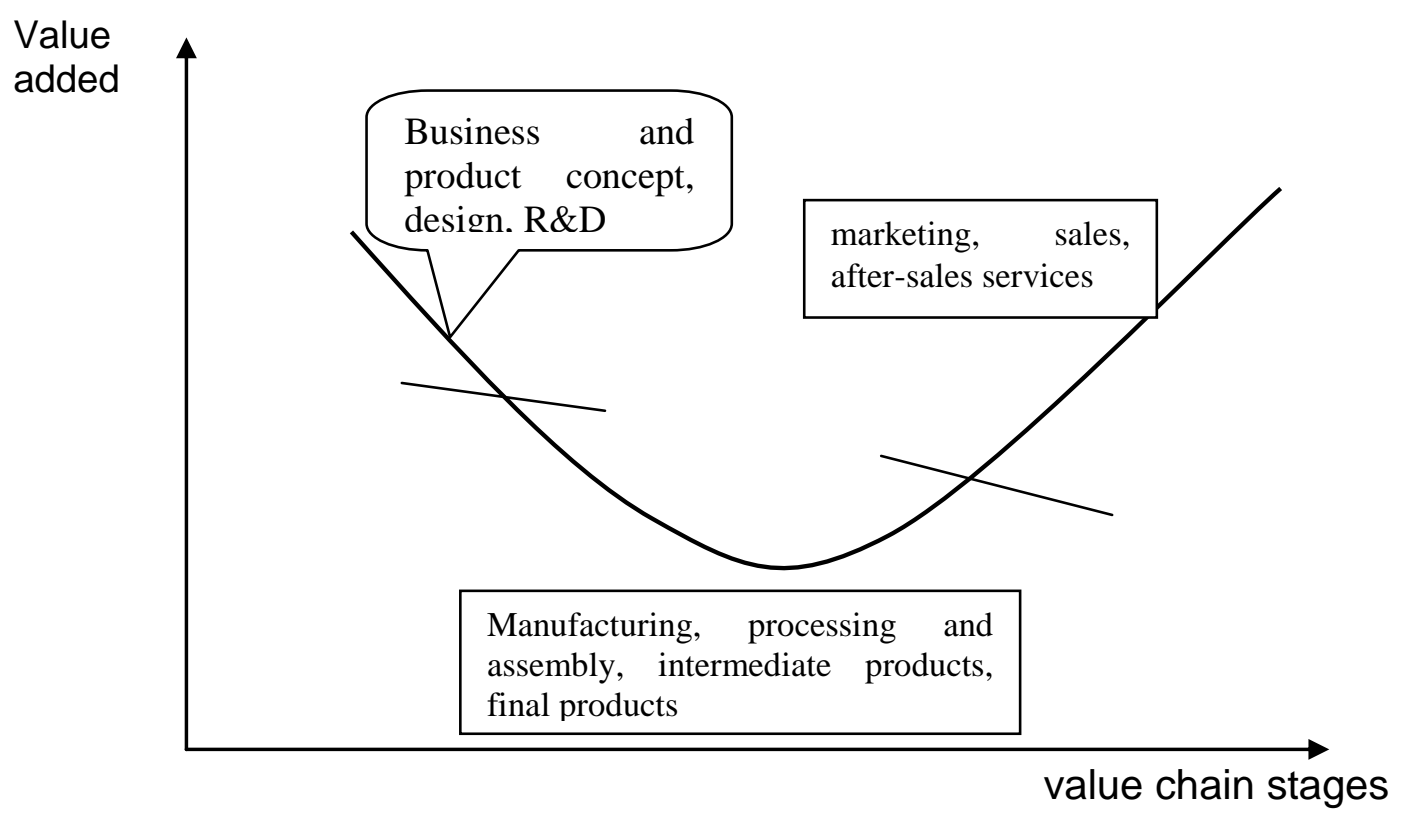

Source: Mudambi, 2008; Baldwin, 2012

\footnotetext{
${ }^{\mathrm{i}}$ Eurostat carried out a survey of enterprises with 100 or more employees in 11 European Member States (plus Norway). Data collection revealed the magnitude and the destination of international sourcing (i.e. the total or partial movement of core and/or support business functions to affiliated or non-affiliated foreign enterprises) in selected European economies. The share of both core and support functions sourced from abroad in the surveyed economies was also investigated:

http://epp.eurostat.ec.europa.eu/statistics_explained/index.php/International_sourcing_statistics

ii According to Rammer at al. (2011: p. 43), the share of LMT industries in total manufacturing value added was $73 \%$ in several EU countries in 2007.

iii In Piekkola's approach organisational capital includes not only the organisational design and business model related intangible assets but customer-related intangibles as well, such as brands trademarks, distribution channels, etc.

iv See e.g. http://www.oecd.org/sti/industryandglobalisation/measuringtradeinvalue-addedanoecdwtojointinitiative.htm or about its use http://www.voxeu.org/article/new-world-input-output-database and the references therein.
} 